\title{
Review / Derleme \\ The vectorial capacity of human lice: Pediculus humanus and Pthirus pubis
}

\author{
Kosta Y. MUMCUOGLU \\ Department of Microbiology and Molecular Genetics, The Kuvin Center for the Study of Infectious and Tropical Diseases, The \\ Hebrew University-Hadassah Medical School, Jerusalem, Israel.
}

Summary: The body louse (Pediculus humanus humanus) is the vector of Rickettsia prowazekii, the agent of epidemic typhus, Borrelia recurrentis, the agent of louse-borne relapsing fever and Bartonella quintana, and the agent of trench fever. Although Acinobacter baumannii and Serratia marcescens have been detected in body lice, their vectorial capacity for these pathogens is not yet clear. Under experimental conditions, it was shown that body lice become infested and later transmit pathogens such as Yersinia pestis, Rickettsia typhi, Rickettsia conorii and Rickettsia rickettsiae, however in these cases it is not known if this could happen under natural conditions. The vectorial ability of head lice remains quite controversial. Under experimental conditions head lice were infected with $R$. prowazekii and disseminate this pathogen in their feces, showing that these lice have the potential to be a vector pathogen under optimal epidemiologic conditions, e.g., during outbreaks of epidemic typhus. Head lice and their eggs collected from children and homeless people were tested positive for B. quintana. Pubic lice are not known to be vectors of any human pathogenic microorganisms under field conditions.

Key words: Pediculus humanus capitis, Pediculus humanus humanus, Pthirus pubis, vector.

\section{İnsan bitleri: Pediculus humanus ve Pthirus pubis'in vektörlük kapasiteleri}

Özet: İnsan vücut biti (Pediculus humanus humanus); epidemik tifüs (salgın tifüs, bit tifüsü, lekeli humma) etkeni Rickettsia prowazekii'nin, bitle bulaşan dönemeli ateş (louse-borne relapsing fever) ajanı Borrelia recurrentis'in ve siper ateşi (trench fever) etkeni Bartonella quintana'nın vektörüdür. Acinobacter baumannii ve Serratia marcescens' in insan vücut bitlerinde varlığı saptamış olmakla beraber insan vücut bitinin bu patojenler için vektörlük kapasiteleri henüz açıklığa kavuşmamıştır. Deneysel koşullar altında, vücut bitinin Yersinia pestis, Rickettsia typhi, Rickettsia conorii ve Rickettsia rickettsiae gibi patojenleri naklettiği gösterilmiş olmakla beraber doğal koşullardaki durumu bilinmemektedir. Baş bitlerinin vektörlük kabiliyetleri oldukça tartışmalıdır. Deneysel koşullar altında baş biti, $R$. prowazekii ile enfekte edilmiş ve patojeni dışkısıyla yaydığı gösterilmiştir ki, bu durum baş bitlerinin optimal epidemiyolojik koşullarda (örneğin epidemik tifüs salgınlarında olduğu gibi) bir patojene vektör olma potansiyelini ortaya koymaktadır. Evsizlerden ve çocuklardan toplanmış baş bitleri ve onların yumurtalarında $B$. quintana'nın varlığ pozitif bulunmuştur. Saha şartlarında, kasık bitlerinin insanlar için patojen herhangi bir mikroorganizmin vektörü olduğu bilinmemektedir.

Anahtar sözcükler: Pediculus humanus capitis, Pediculus humanus humanus, Pthirus pubis, vektör.

Human lice are hematophagous ectoparasitic insects. They are permanent parasites specific to humans, spending their entire life on their host. Humans are parasitized by two species of lice: The human louse, Pediculus humanus, which appears in two ecotypes, the head louse, Pediculus humanus capitis and the body louse, Pediculus humanus humanus. The second species is the pubic louse, Pthirus pubis. Infestation with lice can cause dermatitis and pruritus and as a result of scratching, excoriations and secondary infections may develop. Since the early years of the $20^{\text {th }}$ century, it has been known that body lice are vectors of three pathogenic bacteria: a) Rickettsia prowazekii, the agent of epidemic typhus; b) Borrelia recurrentis, the agent of louse-borne relapsing fever; and c) Bartonella quintana, the agent of trench fever.

\section{A. Vectorial capacity of the body louse (Pediculus humanus humanus)}

History of louse-borne diseases: Historic reports of outbreaks of epidemic typhus date back to the Peloponnesian Wars. The first pestilence that might be attributed to louse-borne typhus was the Athenian Plague of 430 B.C. Thucydides, in his accounts of the Peloponnesian Wars between Athens and Sparta, describes a typhus-like disease that ravaged the Greeks, 
contributing to the downfall of Athens (11). One of the earliest records of the role played by typhus in history is the epidemic that ravaged the army of Ferdinand and Isabella in their attempt to oust the Moors from Spain. In 1489, a Spanish army had blockaded the Moors inside their stronghold at Granada, when an epidemic of louseborne typhus hit the Spanish army and within a month killed approximately 17,000 of the original 25,000 soldiers. As a result, Granada remained in the hands of Moors $(28,29)$. In 1527, Francis I of France was marching into Italy to free the Papal States. Charles V, in charge of the Spanish army in Italy, marched his army out of Rome to fight the French in Naples. Meanwhile, within a short time, epidemic typhus killed 25,000 of the 35,000 French soldiers (7). In his war to subdue the Protestants, Charles V tried to the end the siege of Metz in Germany when 10,000 of his men died from typhus in the first month of the siege. As a result, he failed to subdue Protestantism in Germany and Northern Europe (7).

In 1560, the Ottomans invaded Hungary, the eastern bastion of Christendom. The Austrian army in Hungary fought back but was forced to retreat when typhus killed ca. 30,000 soldiers within three months, leaving Hungary in Turkish hands (7). During the Thirty Years War (1618-1648), next to plague and starvation, typhus was responsible for the loss of 10 million people, while only 350,000 men died in battle (11). During the invasion of Russia, the "Grande Armee", of Napoleon Bonaparte, numbering 600,000 soldiers, while in in Poland, more than 80,000 French soldiers died from epidemic typhus in the first month of the epidemic. Only 90,000 French soldiers reached Moscow, of these only 20,000 returned to France and only 3,000 were still alive in June 1813. In 1813, Napoleon organized another army of 500,000 soldiers to accomplish his campaign, and in that year over 219,000 soldiers died as a result of epidemic typhus, while another 110,000 were killed in battle. It was louseborne epidemic typhus, which defeated Napoleon at Waterloo in 1815 and ended his dreams of a French-ruled world (6).

In 2006, Raoult et al. (22) examined the clothes and skeletal remains of the French soldiers of Napoleon's army, who were buried in a mass tomb in the Ukraine. PCR and sequencing of dental pulp from the remains of 35 soldiers, revealed DNA of $B$. quintana in 7 soldiers and DNA of $R$. prowazekii in 3 other soldiers. The DNA of $B$. quintana was also identified by PCR and sequencing in three of the lice found on the clothes of soldiers. During WWI (1918-1922), 25 million cases of typhus occurred with approx. 3 million deaths, while during WWII major typhus outbreaks occurred throughout Germany, and in 1945 ca. 16,000 cases of typhus were reported. Epidemic typhus was a major problem in the concentration camps; however, it is not known how many inmates died because of this disease. Upon the liberation of Buchenwald, 8,000 inmates were suffering from typhus, and Anna Frank died from the disease in March 1945 in the concentration camp BergenBelsen (7). The last important outbreak of epidemic typhus was observed during the civil war in Burundi (1993-2005), when approximately 100,000 died because of it. Today, this pathogen is endemic in Sudan, Burundi and Ethiopia, but it is considered a pestilence of the past and the World Health Organization classifies it as a "disease under surveillance".

Epidemic typhus (Rickettsia prowazekii): Nicolle et al. (21) brought the first scientific evidence that body lice transmit $R$. prowazekii. Soon after, their observations were confirmed by Ricketts \& Wilder (23) and Goldberger \& Anderson (10). The louse obtains the infection while taking a blood meal from an infected individual. In the midgut of the louse, the rickettsiae enter the epithelial cells and multiply, causing rupture of the cells and concentration of the pathogens in the gut lumen. Sometime later, the microorganisms appear in the feces of the louse. When the louse changes hosts, other individuals become infected by rubbing or scratching the lice feces into their skin, respiration or contact of the pathogens with mucous membranes. Symptoms of epidemic typhus may include chills, cough, delirium, high fever, arthralgia, low blood pressure, headache, myalgia, stupor and a rash that begins on the chest and spreads to the rest of the body. While the early rash is light colored and fades on pressure with time the rash becomes dull and red and does not fade. In severe cases, petechiae are seen on the skin. The treatment includes antibiotics such as doxycycline, tetracycline and chloramphenicol. Without treatment, death occurs in 10$60 \%$ of the cases. In the 1980 's and 1990 's over 80,000 Jewish Ethiopians immigrated to Israel. They came from North and North-Western Ethiopia, where they lived in more than 500 small villages spread over a wide territory-most were concentrated in the area around Lake Tana. After arrival in Israel, ca. 250 children and adults were examined for infestation with head and body lice. Of these, $39 \%$ were infested with body lice and adults were more infested than children. Clinical and serological studies showed that they had no louse-borne diseases (19). Brill-Zinsser disease is a delayed relapse of epidemic typhus. In patients with epidemic typhus, the rickettsia can remain latent and reactivate months or years later, with symptoms similar to the original attack of typhus, including a maculopapular rash. The reactivated rickettsiae could be later transmitted by the body louse, and form the focus for a new epidemic of typhus. $R$. prowazekii was isolated from the flying squirrel Glaucomys volans in the USA, suggesting that an extra-human reservoir of epidemic typhus can exist in a wild animal (3). 
Louse-borne relapsing fever ( $L B R F$ ), caused by $B$. recurrentis, could have been the causative agent of the yellow plague, which ravaged Europe in about $550 \mathrm{AD}$. The famine fevers of the $17^{\text {th }}$ and $18^{\text {th }}$ centuries included typhus, yellow fever and relapsing fever. During WWI a large epidemic of LBRF was observed in West Africa, mainly Nigeria, where close to 140,000 cases were reported. Extensions of these epidemics were also seen in Turkey and Persia in 1920/1. In 1942, LBRF reappeared in and spread throughout Tunisia, Algeria, and Morocco. It appears that there were about 1 million cases and 50,000 deaths. Approximately $10 \%$ of the Tunisian population suffered from LBRF, while in Egypt, an estimated 1.3 million cases were reported. The epidemic was finally brought under control by mass treatment with arsenic and DDT (5). No further serious epidemics of LBRF have been seen since 1946. Today the disease has all but vanished in all areas except the Andean foothills, the Ethiopian highlands and in Rwanda. The ingested Borrelia spirochetes enter the louse gut and cross the epithelium into the hemolymph. It was always thought that transmission to humans occurs by contamination of the abraded skin by the hemolymph of the infected louse. However, recently Houhamdi \& Raoult (13) infected body lice by feeding them on a rabbit made spirochetemic by the injection of borreliae. It was later shown that lice remained infected for life but did not transmit borreliae to their progeny. B. recurrentis infection was observed in hemolymph on day 5 after infection and this pathogen was excreted in lice feces beginning on day 14 after infection, showing that, as with epidemic typhus and trench fever, transmission of louseborne relapsing fever may be caused by lice feces. Using PCR and sequencing techniques, Fournier et al. (9) showed that out of 841 body lice collected from various countries, $R$. prowazekii was detected in body lice from Burundi and Rwanda, B. quintana infections of body lice were widespread, whereas $B$. recurrentis were not found in any of the lice examined.

After an individual is exposed to an infected louse, spirochetes gain access to the bloodstream where they infect the endothelium. The organism then rapidly disseminates to the spleen, liver, lungs, kidneys, central nervous system and bone marrow. Spirochetaemia leads to low-grade disseminated intravascular coagulation and thrombocytopenia. The incubation period ranges from about 4-14 days, after which there is an acute onset of high fever. LBRF is characterized by episodes of fever usually lasting three days, followed by an interval of a week without fever. One to 4 relapses may occur. Additional clinical symptoms include chills, arthralgia, myalgia, constitutional upset, headaches and a dry cough and more rarely a cutaneous rash, jaundice, hemorrhages, photophobia, neurological symptoms, hepatomegaly and splenomegaly, as well as gastrointestinal symptoms such as abdominal pain, nausea, vomiting and diarrhea.

Trench fever (Borrelia quintana): Trench fever caused by $B$. quintana is a moderately serious disease transmitted by body lice. The symptoms include high fever, severe headache, pain on moving the eyeballs, pain in the muscles of the legs and back, and frequently hyperaesthesia of the shins. Recovery can take a month or more and lethal cases are rare although very occasionally the persistent fever leads to heart failure. Aftereffects may include neurasthenia, cardiac disturbances and myalgia. Earlier, trench fever was reported as being one of the diseases, which affected the armies in France, Poland, Galicia, Italy, Salonika, Macedonia, Mesopotamia, as well as in Egyptian and German armies during World War I. from 1915 to 1918, between one-fifth and one-third of all British troops reported ill and were diagnosed with trench fever, while about one-fifth of ill German and Austrian troops had the disease (7). In recent decades, B. quintana infections have emerged in diverse regions of the world such as Russia, France, Japan and the USA, predominantly involving socially disadvantaged persons. This pathogen is now recognized as an agent of bacillary angiomatosis, endocarditis and chronic lymphadenopathy among homeless people $(2,4,18,24,25)$.

Acinobacter baumannii: Acinobacter baumannii is an aerobic gram-negative bacterium, which is resistant to most antibiotics. Some estimates state that the disease kills tens of thousands of U.S. hospital patients each year. The illness can cause severe pneumonia and infections of the urinary tract, bloodstream and other parts of the body. A. baumannii DNA was detected in $21 \%$ of 622 body lice collected worldwide, showing that this pathogen is epidemic in this louse. Recently it was shown that body lice are able to transmit this pathogen (16). In a study conducted by La Scola et al. (18), 161 body lice obtained from homeless patients were studied. B. quintana was isolated and cultured from 15 lice, while the DNA of this parasite was detected in 41 lice by PCR. In addition, Acinetobacter spp. and Serratia marcescens were isolated from these lice.

Serratia marcescens: S. marcescens is a Gramnegative, rod-shaped bacterium in the family Enterobacteriaceae. It was involved in nosocomial infections, particularly catheter-associated bacteremia, urinary tract infections and wound infections in the United States where it was found to be responsible for $1.4 \%$ of nosocomial bacteremia cases. The vectorial capacity of body lice for this pathogen is not yet clear.

Plague (Yersinia pestis): Earlier, Yersinia pestis, the causative agent of plague was found in human body lice during plague outbreaks. To evaluate the role that the human body louse plays as a vector of plague, lice were 
fed on rabbits made bacteremic by intravenous inoculation of 3 strains of $Y$. pestis. The lice remained infected with the strains for their life span and excreted viable organisms in their feces from day 1. Lice infected with 2 virulent strains of $Y$. pestis transmitted the organisms during feeding to uninfected rabbits, which became septicemic and died of plague the following day. Infections were transmitted to naive lice that were fed on these rabbits, showing that lice can be vectors of $Y$. pestis in an experimental model (14).

Endemic or murine typhus (Rickettsia typhi), Mediterranean spotted fever (Rickettsia conorii) and Rocky Mountain spotted fever (Rickettsia rickettsii): Under experimental conditions, it was also shown that body lice are able to transmit Rickettsia typhi, the causative agent of endemic or murine typhus. For this purpose rabbits were made bacteremic by inoculating them with $R$. typhi and remained bacteremic for at least 59 hours. Body lice were infected by feeding on the bacteremic rabbits, when the life span of infected lice was 20 days, less than that of the controls. Infected lice did not transmit $R$. typhi to their progeny. Using the IFA technique, the pathogens were detected in lice feces from day 7 post-infection, and the organism remained viable in feces for up to 80 days as demonstrated by cell culture, indicating that although body lice are not clearly recognized vectors, under certain circumstances they can transmit $R$. typhi (12). Under experimental conditions it was shown that Rickettsia conorii (Mediterranean spotted fever) and Rickettsia rickettsii (Rocky Mountain spotted fever) could be transmitted by body lice (15).

\section{B. Vectorial capacity of the head louse (Pediculus humanus capitis)}

As opposed to body lice, the vectorial ability of head lice remains quite controversial. Murray \& Torrey (20) fed 39 head lice on a rabbit that had been injected intravenously with a virulent strain of $R$. prowazekii. Five days after infection, 16 of them were still alive and were allowed to feed on a human volunteer. Between days 5 and 9, 13 head lice were dead or moribund and all of them were positive by IF for $R$. prowazekii. The three surviving head lice were also positive. The authors concluded that head lice can be readily infected with $R$. prowazekii and disseminate these virulent organisms in their feces, thus they have the potential to be a vector of this pathogen under optimal epidemiologic conditions, e.g., during outbreaks of epidemic typhus. Head and body lice collected from homeless people in San Francisco, California (USA) were tested for B. quintana. It was found that $33.3 \%$ of body lice-infested persons and $25 \%$ of head lice-infested persons had lice infected with B. quintana strain Fuller (2). B. quintana was found in $7 \%$ of head lice and in $18 \%$ of body lice isolated from naturally infested individuals in Ethiopia (8). In head and body lice collected from 30 Nepalese children (including 11 cases of double infestation), B. quintana DNA sequences were detected in both head and body lice from two children as well as in body lice derived from two additional children (26). In addition, the DNA of this pathogen was also detected in head louse eggs collected from a homeless man in Ethiopia (1). In experimental work conducted with head and body lice, the humoral immune response of both lice, following bacterial challenge was examined and it was shown that both exhibited an increased immune response to Staphylococcus aureus but little to Escherichia coli. However, head lice exhibited a significantly higher phagocytotic activity against $E$. coli than body lice, suggesting that the reduced phagocytotic activity in body lice could be responsible, in part, for their increased vector competence (17).

\section{Vectorial capacity of the pubic louse (Pthirus pubis)}

Pubic lice are not known to be vectors of any human pathogenic microorganisms under field conditions. Weyer (27) infected pubic lice rectally with $R$. prowazekii and B. quintana. R. prowazekii developed intracellular in the stomach epithelium but $B$. quintana remained extracellular. Mice could be infected with both pathogens extracted from the stomach tissue of the louse and these lice did not survive an $R$. prowazekii infection.

\section{Acknowledgement}

This article was presented at $1^{\text {st }}$ National Symposium on Vectors and Vector-Borne with International Participation, 9-10 September, 2012, Avanos, Cappadocia, Nevsehir, Turkey.

\section{References}

1. Angelakis E, Diatta G, Abdissa A, Trape JF, Mediannikov O, Richet H, Raoult D (2011): Altitudedependent Bartonella quintana genotype $C$ in head lice, Ethiopia. Emerg Infect Dis, 17, 2357-2359.

2. Bonilla DL, Kabeya H, Henn J, Kramer VL, Kosoy MY (2009): Bartonella quintana in body lice and head lice from homeless persons, San Francisco, California, USA. Emerg Infect Dis, 15, 912-915.

3. Bozeman FM, Masiello SA, Williams MS, Elisberg BL (1975): Epidemic typhus rickettsiae isolated from flying squirrels. Nature, 255, 545-547.

4. Brouqui P, Lascola B, Roux V, Raoult D (1999): Chronic Bartonella quintana bacteremia in homeless patients. N Engl J Med, 340, 184-189.

5. Bryceson AD, Parry EH, Perine PL, Warrell DA, Vukotich D, Leithead CS (1970): Louse-borne relapsing fever. Q J Med, 39, 129-170.

6. Cartwright FF (1972): Disease and History. The Crowell Co., New York.

7. Conlon JM (2012): The historical impact of epidemic typhus. http://entomology.montana.edu/historybug/typhusconlon.pdf Erişim Tarihi: 05.09.2012. 
8. Cutler S, Abdissa A, Adamu H, Tolosa T, Gashaw A (2012): Bartonella quintana in Ethiopian lice. Comp Immunol Microbiol Infect Dis, 35, 17-21.

9. Fournier PE, Ndihokubwayo JB, Guidran J, Kelly PJ, Raoult D (2002): Human pathogens in body and head lice. Emerg Infect Dis, 8, 1515-1518.

10. Goldberger J, Anderson JF (1912): The transmission of typhus fever, with reference to transmission by the head louse (Pediculus capitis). Pub. Health Rep, 27, 297-307.

11. Hare R (1955): Pomp and Pestilence. Philosophical Library, Inc., New York.

12. Houhamdi L, Fournier PE, Fang R, Raoult D (2003): An experimental model of human body louse infection with Rickettsia typhi. Ann N Y Acad Sci, 990, 617-627.

13. Houhamdi L, Raoult D (2005): Excretion of living Borrelia recurrentis in feces of infected human body lice. $\mathrm{J}$ Infect Dis, 191, 1898-1906.

14. Houhamdi L, Lepidi H, Drancourt M, Raoult D (2006): Experimental model to evaluate the human body louse as a vector of plague. J Infect Dis, 194, 1589-1596.

15. Houhamdi L, Raoult D (2006): Experimentally infected human body lice (Pediculus humanus humanus) as vectors of Rickettsia rickettsii and Rickettsia conorii in a rabbit model. Am J Trop Med Hyg, 74, 521-525.

16. Houhamdi L, Raoult D (2006): Experimental infection of human body lice with Acinetobacter baumannii. Am J Trop Med Hyg, 74, 526-531.

17. Kim JH, Min JS, Kang JS, Kwon DH, Yoon KS, Strycharz J, Koh YH, Pittendrigh BR, Clark JM, Lee SH (2011): Comparison of the humoral and cellular immune responses between body and head lice following bacterial challenge. Insect Biochem Mol Biol, 41, 332339.

18. La Scola B, Fournier PE, Brouqui P, Raoult D (2001): Detection and culture of Bartonella quintana, Serratia marcescens, and Acinetobacter spp. from decontaminated human body lice. J Clin Microbiol, 39, 1707-1709.

19. Mumcuoglu KY, Miller J, Manor, Ben-Ishai F, Klaus S (1993): The prevalence of ectoparasites in Ethiopian immigrants. Isr J Med Sci, 29, 371-373.

20. Murray ES, Torrey SB (1975): Virulence of Rickettsia prowazeki for head lice. Ann N Y Acad Sci, 266, 25-34.
21. Nicolle C, Comte C, Conseil L (1909): Transmission expérimentale du typhus exanthématique par le pou du corps. Comptes Rendus Hebdo-Madaires des Séances de l'Académie des Sciences, 149, 486-489.

22. Raoult D, Dutour O, Houhamdi L, Jankauskas R, Fournier PE, Ardagna Y, Drancourt M, Signoli M, La VD, Macia Y, Aboudharam G (2006): Evidence for louse-transmitted diseases in soldiers of Napoleon's Grand Army in Vilnius. J Infect Dis, 193, 112-120.

23. Ricketts HT, Wilder RM (1913): Further investigation regarding the etiology of Tabarillo, Mexican typhus fever. JAMA, 55, 309-311.

24. Rydkina EB, Roux V, Gagua EM, Predtechenski AB, Tarasevich IV, Raoult D (1999): Bartonella quintana in body lice collected from homeless persons in Russia. Emerg Infect Dis, 5, 176-178.

25. Sasaki T, Kobayashi M, Agui N (2002): Detection of Bartonella quintana from body lice (Anoplura: Pediculidae) infesting homeless people in Tokyo by molecular technique. J Med Entomol, 39, 427-429.

26. Sasaki T, Poudel SK, Isawa H, Hayashi T, Seki N, Tomita T, Sawabe K, Kobayashi M (2006): First molecular evidence of Bartonella quintana in Pediculus humanus capitis (Phthiraptera: Pediculidae), collected from Nepalese children. J Med Entomol, 43, 110-112.

27. Weyer F (1952): Experimental infection of Phthirus pubis L. with Rickettsia prowazeki and Rickettsia quintana (in German). Z Tropenmed Parasitol, 3, 302-309.

28. Zinsser H (1934): Varieties of typhus virus and the epidemiology of the American form of European typhus fever (Brill's disease). Am J Hyg, 20, 513.

29. Zinsser H (1963): Rats, Lice, and History. Little, Brown and Co., Boston.

Geliş tarihi: 01.02.2013 / Kabul tarihi: 21.02.2013

Address for correspondence:

Dr. Kosta Y. Mumcuoglu

Department of Microbiology and Molecular Genetics,

The Kuvin Center for the Study of Infectious and

Tropical Diseases,

The Hebrew University - Hadassah Medical School, P.O.Box 12272, Jerusalem 91120, Israel. email:kostam@cc.huji.ac.il 